\title{
焦性沒食子酸アンチモンの構造硎究
}

$\begin{array}{llll}\text { 高 } & \text { 誠 } & \text { 司 } \\ \text { 長 } & \text { 瀨 } & \text { 雄 } & \end{array}$

（東京帝國大學薬學科高木研究室）

（昭和 11 年 3 月 10 日受理)

Seisi Takagi und Yuzo Nagase: Über die

Konstitution des Antimonpyrogallats.

焦性沒食子酸アンチモンに關しては古くは Rosingl), Causse ${ }^{2}$ ), 近〈は Feigl3), Christiansen ${ }^{4}$ ) の報告あり。孰れも其組成を $\mathrm{C}_{6} \mathrm{H}_{5} \mathrm{O}_{4} \mathrm{Sb}$ なりとなし，Feigl 以外の三氏は其構造式として (I) 式を想定せり．獨り Feigl は本物質が錯垍なるべきを想像し (II) 及び (III) の兩式を提出 し殊に（II）式が適當なるを述べたり。

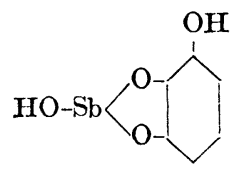

(I)

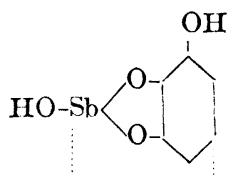

(II)<smiles>O=[Sb]1OC2CCC(O)C1O2</smiles>

(III)

然れども之等構造式の設定に對する樍極的根據は何等西らざるなり．

余等は Dermatol 5 ）赔に次沒食子酸蒼鉛6の構造研究に用みたる方法を應用し, 焦性沒食子 酸アンチモンの構造を追試し類型の物質たるを明にするを得たり。

余等は吐酒石をPyrogallol に作胕し焦性沒食子酸アンチモンを白色微細結晶として得たり. 之を素缺陶板上に 常溫に於て 風乾せしめせしたる後, 之を結晶水の测定站に 元素分析に附し $\mathrm{C}_{6} \mathrm{H}_{5} \mathrm{O}_{4} \mathrm{Sb}+1 / 2 \mathrm{H}_{2} \mathrm{O}$ なる組成を決定せり．即ち之は文丵記載よりも牛分子の水多し，次に之を $110^{\circ}$ に於て乾燥せる後分析せしに文獻記載の $\mathrm{C}_{6} \mathrm{H}_{5} \mathrm{O}_{4} \mathrm{Sb}$ に一致するを知れり.

立得たる物質は $\mathrm{NaOH}, \mathrm{NH}_{4} \mathrm{OH}, \mathrm{Na}_{2} \mathrm{CO}_{3}$ 等アルカリ性溶液に澄明に溶解す. 元來三價の アンチモン監類は $\mathrm{NaOH}$ 等强アルカリには亞アンチモン酸アルカリとなりて溶解すれども, $\mathrm{NH}_{4} \mathrm{OH}, \mathrm{Na}_{2} \mathrm{CO}_{3}$ 等の弱アルカリには全溶せずして亞アチモン酸を沈澱す。從て焦性沒食子酸 アンチモンは單なる Phenolat に非らずして錯盬なるべきを思はしむ.

焦性沟食子酸アンチモンは焦性沒食子酸荅鉛と異りて微量水に溶解し其溶液はリトマス紙に 對して弱酸性を呈す，又其溶液は $\mathrm{FeCl}_{3}$ により活褐色を呈す．之は溶液中に少しく錯解離する 
に依るべし. 又 $\mathrm{NaOH}$ アルカリ性溶液に於てヂメチル硫酸を作用せしめたるに Pyrogallol の Trimethyläther を得をるも，Mono- 或は Di-methyläther を證明し得ず. 從て Pyrogallolの 1-2 筒の HO-基の遊離し居るを證し得ず. 而して Trimethyläther の生成は檢體の 1 部分解 するに依るものと解釋し得へし，郎ち 3 筒の HO-基は同等に陰蔽せられあるものと考へ得へ ᄂ.

次で $\mathrm{NH}_{4} \mathrm{OH}$ アルカリ性溶液に於て $\mathrm{Ba}$ 鹽を製し得たるを以て其 $\mathrm{Ba}$ 及び $\mathrm{Sb}$ を分析せる 飞 $\left[\mathrm{SbC}_{6} \mathrm{H}_{4} \mathrm{O}_{4}\right]_{3} \mathrm{Ba}$ なる組成に適合するを知れり。

更に他方に於て柴时雄次敎授等》の吸收スペクトル法を, Dermatol の研究に利用したると同

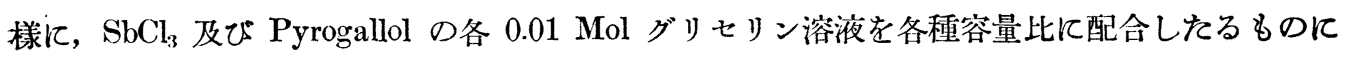
適朋せり，茲に得たる吸收端の波長曲線は Sb:Pyrogallol が $1: 1$ のとき極大を示す. 郎ち此 比率に於て錯監が成立するを知れり。其曲線圖は實驗之部にあリ。

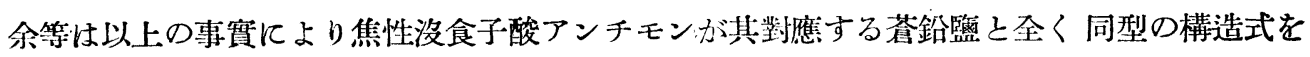
有すべきを類推して，之に下記の式を與へんとす.

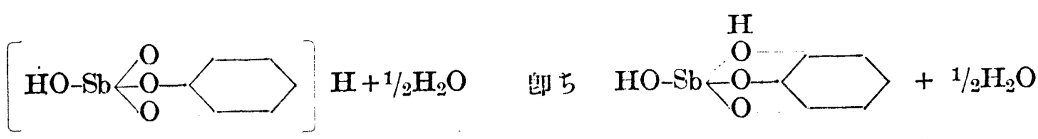

風乾物質

此式を以てすれば所謂焦性沟食子酸アンチモンの化學名は Pyrogallo-monohydroxo-antimonigesäure 乙稱し得へし．且つ此式を以て其諸性状を凡べて容易に說明し得るてとDermatol 及 び焦性沒食子酸蒼鉛の場合と同㥞なるを以て其記述を玆には省略す。

\section{苗 驗之部}

Sb-Pyrogallat の製造及び性:状

吐酒石 $13.0 \mathrm{~g}$ を水約 $200 \mathrm{cc}$ に溶解したる液を Pyrogallol 約 $0.5 \mathrm{~g}$ を水約 $15.0 \mathrm{cc}$ に溶解

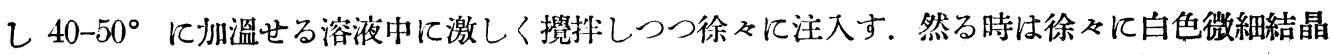
析出し，(其得量は理論值に對し 30 分間放置後には約 $45 \%$ に達し 4 時間放置後には約 $78 \%$ に達す)，立に得たる結晶を初め 2 包傾瀉法により水を以て洗湺し次に滤過して溫湯を以て充 分洗涤したる後, 素燒陶板上に乾燥せしむ。

Sb-Pyrogallol の性狀

多量の水と煮沸する時は溶解してリトマス紙に對して微酸性を呈す。沉に $\mathrm{H}_{2} \mathrm{~S}$ を通ずる時 は硫化物コロイド爿に且つ不完全に沈澱す.

熱湯に溶解せる溶液は $\mathrm{FeCl}_{3}$ により活褐色を呈し， $\mathrm{KMnO}_{4}$ 液を脫色し，且つ $\mathrm{AgNO}_{3}$ を 還元す.

アルコール, エーテル等の倠機性中性溶劑に全く溶解せず. 
本物質は過剩の酒石酸に熱時溶解し，其溶液に $\mathrm{Na}_{2} \mathrm{~S}$ を加ふれば $\mathrm{Sb}_{2} \mathrm{~S}_{3}$ を沈溰す.

$\mathrm{HCl}$ には透明に溶解し， $\mathrm{H}_{3} \mathrm{SO}_{4}$ 又は $\mathrm{HNO}_{3}$ には透明に溶解せず(亞アンチモン酸の析出に 因る).

$\mathrm{NaOH}, \mathrm{Na}_{2} \mathrm{CO}_{3}, \mathrm{NH}_{4} \mathrm{OH}$ に透明に溶解し，亞アンチモン酸を析出せす。.

結晶水の測定 素苌陶板上常溫に於て乾燥せる物質に就て：

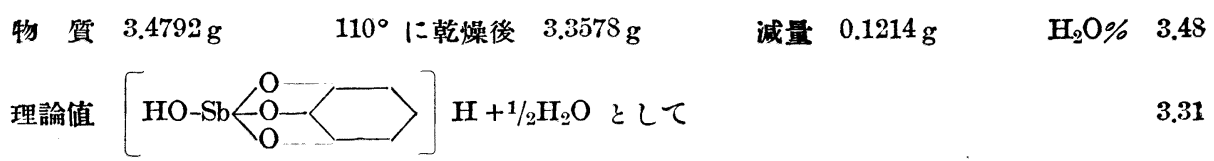

元素分析 (1) 常溫に於て乾燥せるものに就て:

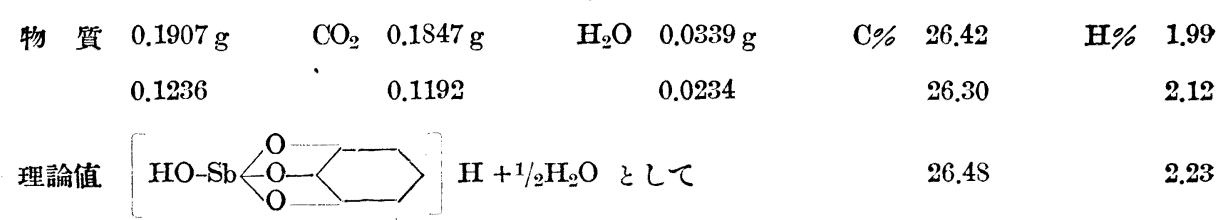

(2) $110^{\circ}$ に於て乾燥せるものに就て:

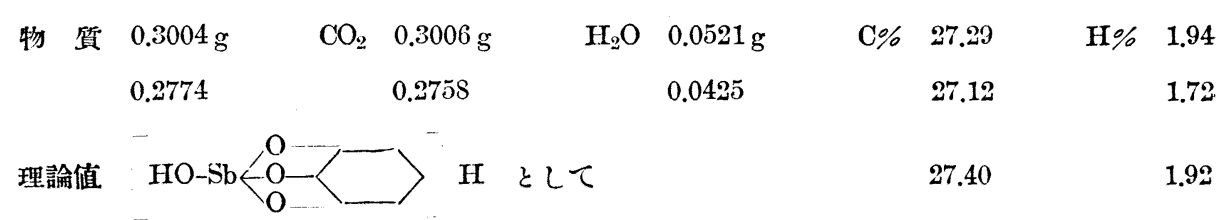

アンチモンの分析 重量分析法に由り $\mathrm{Sb}_{2} \mathrm{~S}_{3}$ として定量せり.

一定量の物質を過剩の酒石酸に加熱溶解せしめ，之に莀 $\mathrm{HCl}$ 約 $1 \mathrm{cc}$ を加へ全量を水を以 て約 $250 \mathrm{cc}$ とし煮沸する迄加熱したる後熱時 $\mathrm{H}_{2} \mathrm{~S}$ を導入す. 熱溶液が全く冷却するに至る迄 $\mathrm{H}_{2} \mathrm{~S}$ を導入し飽和せしめたる後（約 30 分一 1 時間）沈搌をグーチ坩堝中に滤過捕集し $\mathrm{H}_{2} \mathrm{~S}$ を 飽和せる $5 \% \mathrm{CH}_{3} \mathrm{COOH}$ を以て 2-3 包洗滌し, 更に水を以て 1 回洗滌したる後, 空氣不含炭

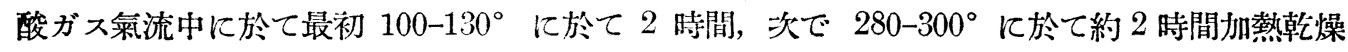
せしめ恒量を得るに至らしむ。

（1）常溫に於て乾燥せるものに就て：
物 質 $0.7308 \mathrm{~g}$
0.3577
$\mathrm{Sb}_{2} \mathrm{~S}_{3} \quad 0.4543 \mathrm{~g}$
0.2228
$\mathrm{Sb} \% \quad 44.56$
44.65
理論值

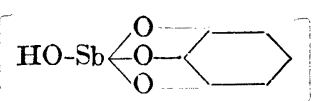
$\mathrm{H}+1 / 2 \mathrm{H}_{2} \mathrm{O}$ として
44.81 
(2) $110^{\circ}$ に於て乾燥せるものに就て：
物 質 $0.4655 \mathrm{~g}$
$\mathrm{Sb}_{2} \mathrm{~S}_{3} \quad 0.2998 \mathrm{~g}$
$\mathrm{Sb} \% \quad 46.17$
0.7326
0.4711
46.10
理論值
$[\mathrm{HO}-\mathrm{Sb}\langle\mathrm{O}-\longrightarrow \mathrm{O}<\iota \succ$
46.35

Sb-Pyrogallat のメチル化試驗

Sb-Pyrogallat 約 $10 \mathrm{~g}$ を篦素氣流中に於て $20 \% \mathrm{NaOH} 20 \mathrm{cc}$ 亿溶解せしめ, 此上に徐※に ヂメチル硫酸 $10 \mathrm{cc}$ を注加し, 時く冷却しつつ約 3 時間振蕰したる後, 稀 $\mathrm{HCl}$ を以て酸性之 なす. 泣に得たる鹽酸酸性溶液にクロロホルムを加へて數回振盪浸出す。

クロロホルム可溶部分は之よりクロロホルムを溜去し, エーテルより再結晶を行ひ, 無色結 晶を得たり．此結晶は水に不溶にして $\mathrm{FeCl}_{3}$ によつて着色せず且つ全く還元性を有せす。. 其 Fp. $44^{\circ}$ イしてトリメトオキシベンジールと混融するに Fp. $45^{\circ}$ を示す. 故に立に得をる結晶. はトリメトオキシベンジールに一致せるととを確定せり. 其收得量 $1 \mathrm{~g}$ 强.

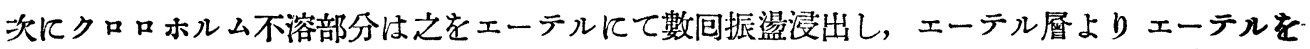
溜去するに帶褐色殘渣を留む. 此殘渣を酒精より 2 回再結晶し無色結晶を得たり. 此結晶は水 に可溶にして $\mathrm{FeCl}_{3}$ により暗綠色を呈し，又還元作肘を呈す．其 $\mathrm{Fp}$. は $131^{\circ}$ にしてピロガ口 ールと混融するに $131^{\circ}$ を示す. 故に其結晶はピロガロールなるととを確定す. 其收得量 $2 \mathrm{~g}$ 弱.

\section{Sb-Pyrogallat $の \mathrm{Ba}$ 監}

Sb-Pyrogallat $5 \mathrm{~g}$ を窒素氣流中に於て $\mathrm{NH}_{4} \mathrm{OH}(10 \%)$ 約 $15 \mathrm{cc}$ に溶解し之に熱湯約 $50 \mathrm{cc}$ を加へをる後, 之に $\mathrm{Ba}(\mathrm{OH})_{2} \cdot 8 \mathrm{H}_{2} \mathrm{O} 3 \mathrm{~g}$ を炭酸不会の蒸溜水約 $20 \mathrm{cc}$ 亿溶解せる熱溶液を徐 及に注入す. 立に生成せる白色無定形沈澱を空素氣流中にて滤過し $\mathrm{Ba}(\mathrm{OH})_{2}$ 稀溶液にて数回 洗涤し，溫湯を以て 1-2 包洗滌後減壓下に乾燥せし气。

玆に得たる白色沈澱は不安定にして水分の存在に於て空氣に觸れて速に褐變す。アルカリ淊. 液及び酸に可溶, 水に殆ど不溶なり。

$\mathrm{Sb}$ 及び Ba の定量 Sb-Subgallat の $\mathrm{Ba}$ 敬の場合 (218 頁參照) と同樣にアンチモンは $\mathrm{Sb}_{2} \mathrm{~S}_{3}$ として，叉バリウムは $\mathrm{BaSO}_{4}$ として重量分析法により定量せり.
物 筫 $0.3964 \mathrm{~g}$
$\begin{array}{ll}\mathrm{Sb}_{2} \mathrm{~S}_{3} & 0.2019 \mathrm{~g}\end{array}$
$\mathrm{BaSO}_{4} \quad 0.1414 \mathrm{~g}$
$\mathrm{Sb} \% \quad 36.51$
$\mathrm{Ba} \% \quad 20.99$
理諭值

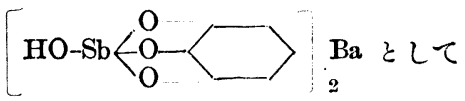
36.84
20.78

$$
\text { 吸收スペクトル法による錯監生成の證明 }
$$

Dermatol の構造研究に於て述べたると同樣に操作せり，郎ち石英分光器 (Adam Hilger

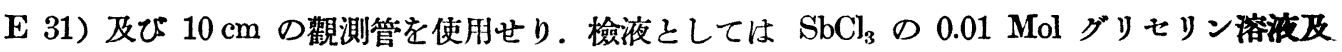

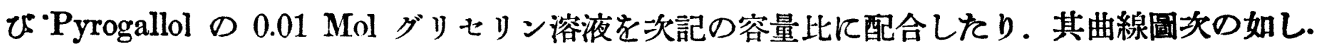




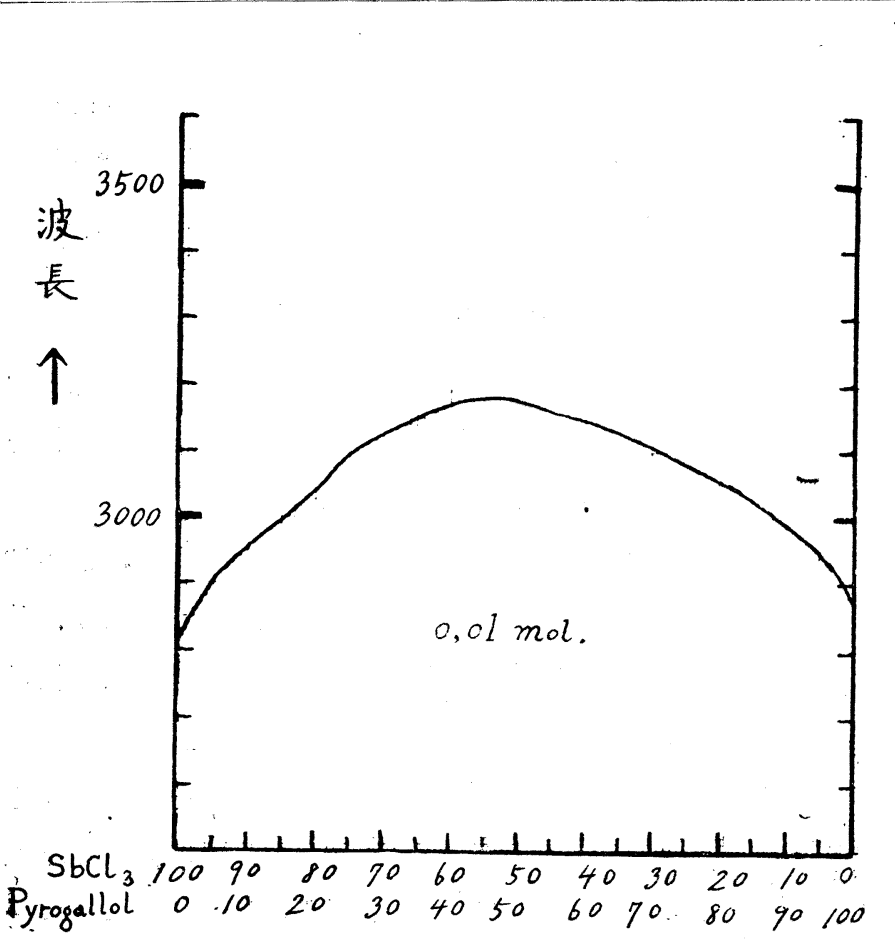

\begin{tabular}{|c|c|c|}
\hline \multicolumn{3}{|c|}{ （溶媒: グリセリン） } \\
\hline & 合の割合 & 波長の \\
\hline $\mathrm{SbCl}_{3}$ & Pyrogallol & 吸收端 \\
\hline $100 \%$ & $0 \%$ & 2815 \\
\hline 95 & 5 & 2905 \\
\hline 90 & 10 & 2953 \\
\hline 85 & 15 & 2990 \\
\hline 80 & 20 & 3038 \\
\hline 75 & 25 & 3095 \\
\hline 70 & 30 & 3130 \\
\hline 65 & 35 & 3150 \\
\hline 60 & 40 & 3170 \\
\hline 55 & 45 & 3180 \\
\hline 50 & 50 & , \\
\hline 45 & 55 & 3165 \\
\hline 40 & 60 & 3150 \\
\hline 35 & 65 & 3135 \\
\hline 30 & 70 & 3110 \\
\hline 25 & 75 & 3080 \\
\hline 20 & 80 & 3055 \\
\hline 15 & 85 & 3025 \\
\hline 10 & 90 & 2980 \\
\hline 5 & 95 & 2955 \\
\hline 0 & 100 & 2880 \\
\hline
\end{tabular}

\section{文獻}

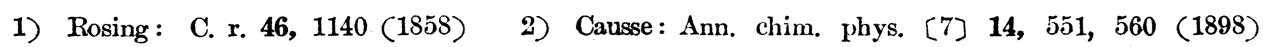
3) Feigl: Fr. 64, $41(1924)$ 4) Christiansen: Am. 48, 1358-69 (1926) 5) 本誌： 56, 92 （昭和 11 年 2 月號） 6) 本誌：56, 202 （昭和 11 年 3 月號） 7) 柴田雄次, 井上敏, 中塚作一： 42, 983 (大正 10 年); 日本化學輯報 1, 1; 木村健次郎：化 54, 1 (昭和 8 年); 高木, 長濑: 本誌 56, 95 (昭和 11 年 2 月號) 